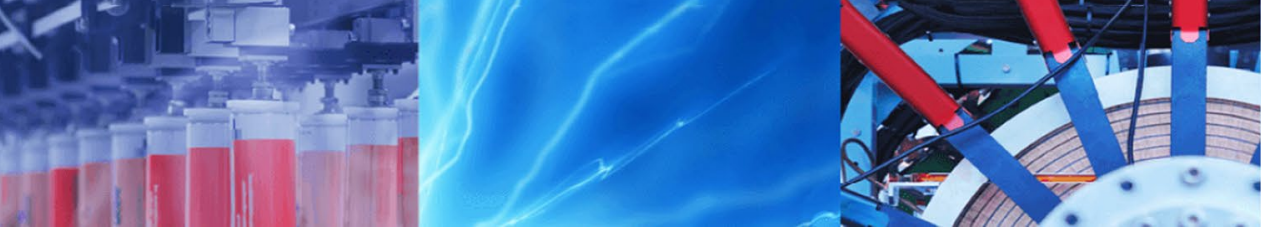

Research Article

\title{
Development of novel electrochemical sensor for the detection of biological warfare agents: enzyme, antibody, and DNA free
}

\author{
Harish Kumar ${ }^{1}\left[\right.$ [ $\cdot$ Bhawana Gupta ${ }^{2}$
}

Received: 1 August 2020 / Accepted: 14 October 2020 / Published online: 7 November 2020

(c) Springer Nature Switzerland AG 2020

\begin{abstract}
There is an urgent need to develop a novel sensor that can quickly and accurately detect biological warfare agents (BWAs). A novel electrochemical sensor was specially designed and developed for Staphylococcus aureus as a potential BWAs without using any enzyme, antibody, or genetic material. Cyclic voltammetry (CV), linear resistance polarization (LRP), chronoamperometry, impedance spectroscopy, and Differential Pulse Voltammetry (DPV) techniques were used for fast and accurate detection of BWAs. Co-precipitation technique was used for the synthesis of CuO nanoparticles (NPs) for their use in the electrochemical sensor. The effect of temperature, stirring and addition of CuO NPs was thoroughly investigated. The storage, stability, and performance of electrochemical sensor was tested for 45 days. The current response of the electrochemical sensor was found linear with the correlation coefficient, $R^{2}=0.991$. The major advantage of this novel electrochemical sensor is that immobilization of enzyme, antibody, or DNA is not required in sensing technology as the immobilization process makes biosensors a highly specific. The novel electrochemical sensor was very quick, accurate, non-specific, and provide reliable results in the qualitative and quantitative estimation of pathogenic bacteria as a potential BWAs.
\end{abstract}

Keywords Biological warfare agents · Electrochemical sensor · Cyclic voltammetry · S. aureus · Copper oxide nanoparticles - Differential pulse voltammetry

\section{Introduction}

A biological weapon is more fatal than a chemical weapon. Terrorists deliberately add disease-causing biological agents like bacteria, spores or viruses, etc. into the environment to infect a large section of society. A technique which is very quick and reliable is essentially required for the determination of BWAs so that life of thousands of people can saved by knowing the nature and type of infection. Several pathogenic bacteria fall under the category of possible biological warfare agents (BWAs) [1]. However, highly dangerous include Botulinum toxin, Francisella tularensis, Salmonella typhimurium, Staphylococcus epidermis, Vibrio vulnificus, etc. Others i.e., V. E. encephalitis,
Ebola, Marburg, infectious viruses, etc. are rarely used as a biological weapon because they are not easily available.

There are different types of electrochemical biosensors i.e., impedance, potentiometer, conductance and amperometric [2-5]. Among these, amperometric biosensors are quick, reliable, sensitive, and most of them are composed of ion-membrane electrodes [6]. Si-Jing Huang and his co-workers have developed the wireless magnetoelastic sensor to detect $S$ aureus in two different mediums i.e., cell culture medium and milk [7]. Yi Xu and his co-workers have investigated thermal parameters in a column filled with different size micro-particles as a reactor in thermal biosensor [8]. Hala Ghali and his co-workers have reported WGM (Whispering Gallery Mode) micro-resonators optical

$\square$ Harish Kumar, harishkumar@cuh.ac.in | 'Department of Chemistry, School of Basic Sciences, Central University of Haryana, Mahendergarh 123 031, India. ${ }^{2}$ Department of Chemistry, Ch. Devi Lal University, Sirsa, Haryana 125055, India. 
micro-disks-based biosensors for detection of S. aureus [9]. Chibli and his research group have immobilized specific phage proteins on silicon wafers to bind staphylococci with the help of micro-resonators optical disk [10]. Chang et al. have reported that $\mathrm{S}$. aureus is a hypersensitive $\mathrm{H}_{2} \mathrm{O}_{2}$ sensor using Fe-mediated histidine oxidation and proved their results by using Fluorescence spectroscopy [11, 12]. Zhu et al. have reported carbon nanospheres coupled with Ag NPs and endonucleases to sense DNA by using the electrochemical stripping method [13]. Fenglei et al. have developed the electrochemical immune assay strategy to detect carcinoembryonic antigen by using a nucleic acid probe in presence of ferrocene [14]. Few others have reported electrochemical sensors for theophylline [15], acetaminophen [16], rifampicin [17], and pyrazinamide [18].

S. aureus is a major nosocomial pathogen worldwide. It is still in the list of major drug resistance bacteria and it is a frequent and important human pathogen. It was first reported in Britain in 1960 and later in the western countries in 1970. Infections caused by S. aureus is a very serious problem all over the world, as it is resistant to many antibiotics and transmit from patient to patient. The diseases caused by $S$. aureus include gastric, colorectal, recurrent cancer, and bowel obstruction followed by gastrostomy.

To the best of our knowledge, no researchers have reported the electrochemical sensor for $S$. aureus pathogenic bacteria at different temperatures by qualitative and quantitative manner without using any enzyme, antibody, or genetic material. In continuation to our study [19-23], here we have focused on three electrodes based novel electrochemical sensors for the quick, accurate, non-specific, and reliable detection of $S$. aureus pathogenic bacteria a potential BWAs. Reported work makes use of either enzyme, antibody, protein, or DNA moiety for immobilization over the surface of the working electrode for selective determination of the particular analyte. Different working electrodes have to be designed and fabricated for a specific analyte. But this novel electrochemical sensor solves this problem of specificity of the biosensors. This novel sensor can be used for the qualitative and quantitative estimation of different types of analytes, biological warfare agents, and environmental pollutants. The co-precipitation technique was used for the synthesis of CuO NPs. These NPs act as electron mediator in the working electrode. UVvisible, FTIR, TEM, TGA, and XRD techniques were used for the characterization of $\mathrm{CuO}$ nanoparticles. Cyclic voltammetry, linear resistance polarization, chronoamperometry, impedance spectroscopy, and Differential Pulse Voltammetry (DPV) techniques were used for the quick and correct detection of S. aureus pathogenic bacteria. The sensor was tested for 45 days for storage, stability and re-usability condition.

\section{Materials and method}

S. aureus bacteria (MTCC No. 3160) were collected from the Institute of Microbial Technology, Chandigarh, Haryana. $\mathrm{Cu}\left(\mathrm{NO}_{3}\right)_{2} \cdot 3 \mathrm{H}_{2} \mathrm{O}$ (AR grade, 99.5\%), $\mathrm{CuSO}_{4} \cdot 5 \mathrm{H}_{2} \mathrm{O}$ (AR grade 99\%) and ethyl acetate (AR grade $99.5 \%$ ) were procured from Sisco Res. Lab. Pvt. Ltd. (SRL), India. Sodium phosphate buffer solution (99.5\%) was procured from SigmaAldrich Pvt. Ltd.

The experimental technique was performed in five steps:

\subsection{Bacterial strain preparation}

The S. aureus was grown-up in nutrient broth in pre-sterilized Petri plates using laminar flow at a constant temperature of $37^{\circ} \mathrm{C}$. A sodium phosphate buffer solution (SPBS) was used for culturing the bacteria.

\subsection{Co-precipitation method for $\mathrm{CuO}$ nanoparticles}

Co-precipitation technique was used for the synthesis of $\mathrm{CuO}$ NPs. The copper nitrate and copper sulfate solutions were mixed together with constant stirring and sodium hydroxide solution was added with gentle heating. Ageing, nucleation, and the seedling process was carefully observed till the complete precipitation of CuO NPs.

\subsection{Characterization of CuO NPs}

Characterization of CuO NPs was carried out by UV-visible, X-ray diffraction, FTIR spectroscopy, Thermogravimetric analysis (TGA), and Transmission Electron Microscopy (TEM) techniques.

\subsection{Designing of working electrode and assembling of electrochemical cell}

For the detection of $S$. aureus pathogenic bacteria, three electrodes based electrochemical cell was used having a working electrode, Silver/Silver chloride (reference electrode), and a Pt electrode as an auxiliary electrode. Figure 1 shows a schematic diagram of an electrochemical cell for the electrochemical characterization of diseasecausing pathogenic bacteria. The working electrode was specially designed and fabricated for the electrochemical characterization of pathogenic bacteria, or spores. A glass dropper was selected for this purpose. At its tip, a thick copper wire was inserted which was flattened to increase the surface area for electrochemical 
reactions. From the other open end, a slurry was added with the help of a syringe made up of butyl carbitol acetate + ethyl acetate mixture acting as conducting binder, $0.1 \mathrm{M}$ sodium phosphate buffer solution (SPBS), CuO NPs, and graphite powder. $\mathrm{CuO}$ NPs here acts as redox mediator instead of Cytochrome-C or Ferrocene commonly used in CV measurements. A few advantages of using CuO NPs as redox mediator are: high order of conductivity, large surface area, small size, high catalytic activity, and high adsorption capacity. This newly designed working electrode along with reference and auxiliary electrodes are inserted into a double wall jacketed glass cell connected to a potentiostat (PGSTAT $128 \mathrm{~N}$ ) acting as a transducer that converts the electrochemical response into an electrical signal.

\subsection{Electrochemical characterization and detection of pathogenic bacteria}

The electrochemical characterization experiments like LRP, CV, Chronoamperometry, Electrochemical Impedance Spectroscopy (EIS), and DPV were carried out on a potentiostat (PGSTAT $128 \mathrm{~N}$ ) attached with a PC and digitally controlled water bath to maintain a constant temperature. SPBS was used for holding the bacterial culture. The effect of the addition of CuO NPs, heating, and stirring was thoroughly investigated. Change in Open Circuit Potential $(\mathrm{OCP})$, current $\left(\mu \mathrm{A} / \mathrm{cm}^{2}\right)$ and oxidative anodic peak $E_{p a^{\prime}}$ and reductive cathodic peak $E_{p c^{\prime}}$ midpoint potential $E_{M I D}, \Delta E_{p \text {, }}$ maximum current in anodic direction $I_{p}$, and formal potential $E_{c}{ }^{\theta}$ were recorded under different conditions. Definite

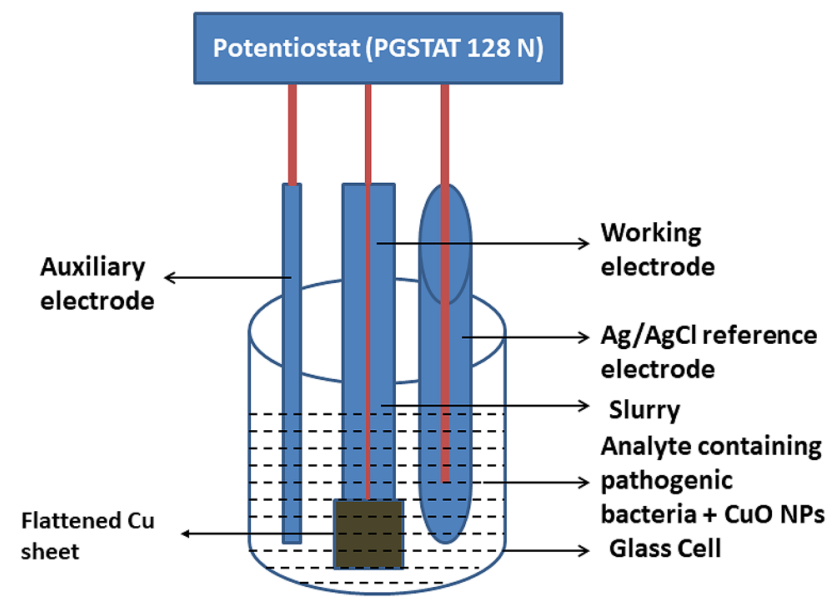

Fig. 1 Electrochemical sensor (Enzyme, antibody and DNA free) for the detection of $S$. aureus pathogenic bacteria in presence of $\mathrm{CuO}$ NPs as a potential biological warfare agent. Three electrodes i.e. working, reference and counter electrode are connected to potentiostat (PGSTAT $128 \mathrm{~N}$ ) acting as transducer which convert electrochemical response in to an electrical signal values of an oxidative anodic peak, mid-point potential, formal potential, and OCP provides qualitative information i.e., nature and type of pathogens. The maximum current density on the anode provides quantitative information, i.e., concentration of BWAs.

$1 \times 10^{7} \mathrm{CFU} / \mathrm{mL}$ of pathogenic bacteria was taken in $50 \mathrm{~mL}$ of SPBS. Four different samples were taken for study i.e. Sample 1: Pure SPBS, Sample 2: SPBS with $1.0 \times 10^{7} \mathrm{CFU} /$ $\mathrm{mL}$ of bacteria, Sample 3: SPBS with CuO NPs, and sample 4: SPBS with CuO NPs and $1.0 \times 10^{7} \mathrm{CFU} / \mathrm{mL}$ of pathogenic bacteria. The effects of continuous stirring, heating $\left(70^{\circ} \mathrm{C}\right)$, and the effect of the addition of CuO NPs (100 ppm) was thoroughly investigated. The observations made after $4 \mathrm{~h}$ are current density $\left(\mu \mathrm{A} / \mathrm{cm}^{2}\right)$, equilibrium and non-equilibrium potential $(\mathrm{mV})$, oxidative peak, reductive peak, $E_{M I D^{\prime}}$ $\Delta E_{p^{\prime}} E_{p a^{\prime}} E_{p c^{\prime}} E_{c}^{\theta}$ and variation in current values with time.

\section{Results and discussion}

Tables 1, 2 and 3 and Figs. 2, 3, 4, 5, 6, 7, 8 and 9 show the results of the electrochemical characterization of $S$. aureus pathogenic bacteria. Table 1 represents the OCP of stirred and unstirred samples of $S$. aureus with CuO NPs. Table 2 shows the OCP of heat-treated samples of $S$. aureus without CuO NPs. Table 3 shows the effect of stirring, heating, and addition of $\mathrm{CuO}$ NPs and their effect on the current density $\left(\mu \mathrm{A} / \mathrm{cm}^{2}\right), \mathrm{OCP}$, oxidative peak, reductive peak, $E_{p a^{\prime}}$ $E_{M I D}, \Delta E_{p}, E_{c}{ }^{\theta}$ and limit of detection (LOD). Table 4 shows the results of the electrochemical impedance spectroscopy technique.

\subsection{Characterization of CuO NPs}

CuO NPs were characterized by UV-visible, FTIR, XRD, TGA, and TEM techniques (Fig. 10). Figure 10(a) shows the UVvisible spectra of $\mathrm{CuO}$ NPs synthesized by the co-precipitation method. In the UV-visible spectra absorption peaks were observed at 250 and $300 \mathrm{~nm}$. The FT-IR spectra shows two peaks at 668.05 and $620.93 \mathrm{~cm}^{-1}$ in the fingerprint region corresponding to CuO NPs Fig. 10(b). A broad peak

Table 1 Open circuit potential (OCP) values of unstirred and stirred samples of $\mathrm{S}$. aureus with $\mathrm{CuO}$ nanoparticles

\begin{tabular}{llll}
\hline S. No. & Samples & $\begin{array}{l}\text { OCP values } \\
\text { (volt) At 0 h }\end{array}$ & $\begin{array}{l}\text { OCP values } \\
\text { (volt) after } \\
4 \mathrm{~h}\end{array}$ \\
\hline 1. & Pure PBS solution & 0.203 & 0.141 \\
2. & $\begin{array}{l}\text { PBS solution with CuO NPs } \\
\text { (100 ppm) }\end{array}$ & 0.182 & 0.386 \\
3. & $\begin{array}{l}\text { PBS solution with CuO NPs } \\
\text { (100 ppm) and S. aureus. }\end{array}$ & 0.347 & 0.157 \\
\hline
\end{tabular}


Table 2 Open circuit potential (OCP) values of heat-treated samples of S. aureus with $\mathrm{CuO}$ nanoparticles

\begin{tabular}{llll}
\hline S. No. & Samples & $\begin{array}{l}\text { OCP values } \\
\text { (volt) at } \mathrm{h} \mathrm{h}\end{array}$ & $\begin{array}{l}\text { OCP values } \\
\text { (volt) after } \\
4 \mathrm{~h}\end{array}$ \\
\hline 1. & PBS solution with S. aureus & 0.137 & 0.109 \\
2. & $\begin{array}{c}\text { PBS solution with S. aureus } \\
\text { and CuO NPs (100 ppm) }\end{array}$ & 0.140 & 0.115 \\
& & \\
\hline
\end{tabular}

from 3000 to $3500 \mathrm{~cm}^{-1}$ may be due to $\mathrm{OH}^{-}$ion present as impurity absorbed by the sample in the form of moisture from the atmosphere. Figure 10(c) shows the XRD pattern of $\mathrm{CuO} N P s$. The peaks at $2 \theta$ values $24.74,32.42,34.46$, and $35.72^{\circ}$ are indexed at $021,110,002$, and 111 , respectively. It is clear from the X-ray diffraction pattern that synthesized CuO NPs are crystalline $[24,25]$. The average particle size of CuO NPs as calculated from the Scherrer equation corresponding to a maximum intensity peak was $70 \mathrm{~nm}$. Figure 10(d) shows the TEM image of CUO NPs. The average size of CUO NPs as observed from TEM image was 60-80 nm. Figure 10(e) shows thermogravimetric analysis (TGA) of CuO NPs. The NPs were found to be very stable up to $600^{\circ} \mathrm{C}$ and most of the weight loss take place at $200^{\circ} \mathrm{C}$ after that weight loss was very small. CuO NPs get completely vaporized at $800^{\circ} \mathrm{C}$.

\subsection{Linear resistance polarization (LPR) method}

Figure 2 shows Tafel plots for the electrochemical polarization of the working electrode exposed to $S$. aureus pathogenic bacteria. Figure 2(a) shows Tafel plots of SPBS at the start and end ( $4 \mathrm{~h}$ ) of stirring at $600 \mathrm{rpm}$ obtained from LRP experiments. Figure 2(b) shows Tafel plots of SPBS $+\mathrm{CuO}$ NPs. Figure 2(c) shows Tafel plots of SPBS $+S$. aureus. Figure 2(d) shows Tafel plots of SPBS, S. aureus and $\mathrm{CuO}$ NPs. Although LRP method provides a little information about the qualitative estimation of pathogenic bacteria but it provides useful information about the presence and absence of quasi-equilibrium, direction of shift in OCP, current density $\left(i_{\text {corr }}\right)$, anodic and cathodic Tafel slopes $\left(\beta_{a}\right.$ and $\left.\beta_{c}\right)$ in presence and absence of pathogenic bacteria. The Tafel slopes tell us about the shifting of equilibrium and kinetics of electrochemical reaction at the surface of the working electrode $[26,27]$. The addition of CuO NPs (100 ppm) results in the decrease in OCP and current density $\left(i_{\text {corr }}\right)$, i.e., a shift towards a more noble direction Fig. $2(\mathrm{a}, \mathrm{b})$. The heating at $70^{\circ} \mathrm{C}$ and addition of CuO NPs (100 ppm) have the same effect on the behavior of the electrochemical system and results in the killing of S. aureus pathogenic bacteria (Fig. 2(c, d) and Table 2). Results of LRP are in closed agreement with CV, chronoamperometry, impedance spectroscopy, and DPV techniques.

\subsection{Cyclic voltammetry (CV) method}

Figure 3 shows the cyclic voltammogram (CV) performed on pathogenic bacteria in presence and absence of NPs. Figure 3(a) shows the cyclic voltammogram of SPBS at $0 \mathrm{~h}$ and after $4 \mathrm{~h}$ of stirring at $600 \mathrm{rpm}$. Figure $3(\mathrm{~b})$ shows the CV curves of SPBS + CuO NPs. Figure 3(c) shows the CV curves of SPBS and S. aureus. Figure 3(d) shows the CV curves of SPBS, S. aureus and CuO NPs.

The electrochemical process taking place at the surface of the working electrode is reversible or Nerstian in nature and is majorly diffusion controlled (Fig. 3). At a slow scan rate, the process was thermodynamically controlled where at a high scan rate the process was kinetically controlled $[28,29]$. It was observed during our experiments that as we increase the scan rate (at constant temperature and fixed concentration, i.e., $1.0 \times 10^{7} \mathrm{CFU} / \mathrm{mL}$ of S. aureus) than activation energy or height of oxidative and reductive peaks in CV increases and hence electrochemical reactions becomes more and more kinetically controlled as compared to low scan rate (Fig. 3) where peak height was
Table 3 Effect of stirring, heating and addition of $\mathrm{CuO}$ nanoparticles (100 ppm) on the values of current $\left(\mu \mathrm{A} / \mathrm{cm}^{2}\right)$, potential (OCP), oxidative peak $E_{p a}$ mid-point potential $E_{M I D^{\prime}}$ difference in potential $\Delta E_{p^{\prime}}$ and formal potential $E_{c}{ }^{\theta}$

\begin{tabular}{|c|c|c|c|c|}
\hline Effect of stirring, heating and CuO NPs & $\begin{array}{l}\text { Open circuit } \\
\text { potential }(\mathrm{mV})\end{array}$ & Current $\left(\mu \mathrm{A} / \mathrm{cm}^{2}\right)$ & $\begin{array}{l}\text { Oxidative } \\
\text { peak }(\mathrm{mV})\end{array}$ & $\begin{array}{l}\text { Reductive } \\
\text { peak }(\mathrm{mV})\end{array}$ \\
\hline Stirring & 157 & -0.467 & -0.867 & -0.267 \\
\hline Heating $\left(70^{\circ} \mathrm{C}\right)$ & 109 & 0.990 & -0.906 & 0.168 \\
\hline CuO NPs (100 ppm) & 115 & 0.011 & -0.917 & 0.180 \\
\hline S. aureus & $\mathrm{E}_{\mathrm{pa}}$ & $\mathrm{E}_{\mathrm{MID}}$ & $\Delta \mathrm{E}_{\mathrm{p}}$ & $\mathrm{E}_{\mathrm{c}}^{\theta}$ \\
\hline $1 \times 10^{7} \mathrm{CFU} / \mathrm{mL}$ & $-0.85 \mathrm{~V}$ & $-0.075 \mathrm{~V}$ & $-0.15 \mathrm{~V}$ & $0.075 \mathrm{~V}$ \\
\hline Limit of detection (LOD) in CFU/mL & $1 \times 10^{9 a}$ & $2 \times 10^{7}(\text { cells } / \mathrm{mL})^{b}$ & $5 \times 10^{6 c}$ & $5 \times 10^{3 d}$ \\
\hline
\end{tabular}

${ }^{a}$ Limit of detection observed by our novel electrochemical sensor

${ }^{b}$ Limit of detection observed by Haung et al. [7]

'Limit of detection observed by Ghali et al. [9]

${ }^{d}$ Limit of detection observed by Chibli et al. [10] 


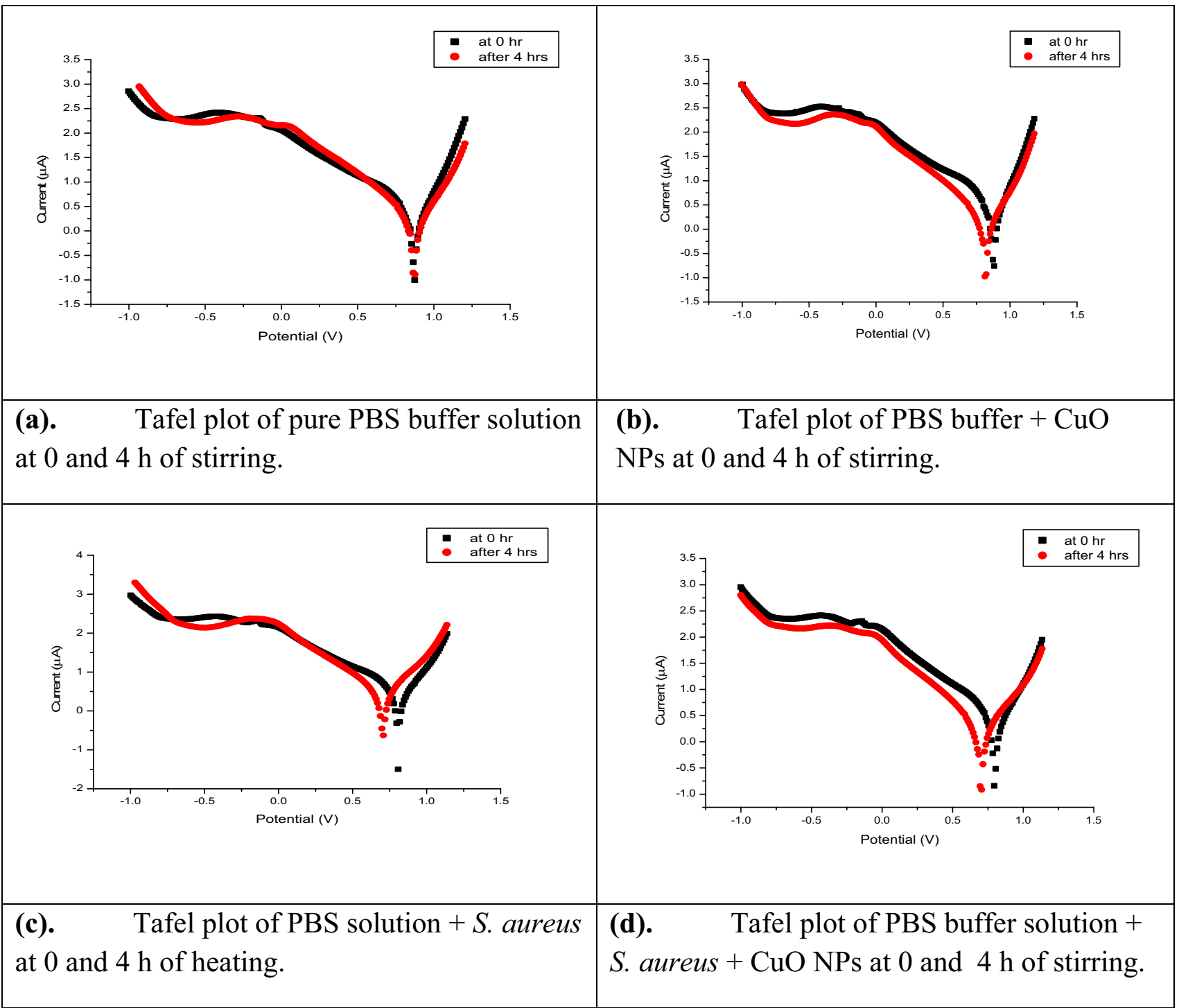

Fig. 2 Tafel plots for electrochemical characterization of S. aureus pathogenic bacteria. All potentials were recorded with a $3 \mathrm{~mm}$ graphite working electrode w.r.t. $\mathrm{Ag} / \mathrm{AgCl}$ reference electrode in $1.0 \times 10^{7} \mathrm{CFU} / \mathrm{mL}$ of $S$. aureus in $50 \mathrm{~mL}$ of PBS buffer solution and at

less and hence thermodynamically controlled. The shape of CV curves depends basically on two important laws: (i) Fick's law of diffusion and (ii) Nernst's law, Eqs. (1) and (2), respectively.

$\frac{\partial[A]}{\partial t}=D \frac{\partial^{2}[A]}{\partial x^{2}}$

$\frac{[A]_{x=0}}{[B]_{x=0}}=e^{\frac{n F}{R T}}\left(E_{t}-E_{c}^{\theta}\right)$

Here, $[A]_{x=0}$ and $[B]_{x=0}$ are the surface concentration of the oxidized and reduced form of electroactive species, respectively. $\mathrm{n}$ is the number of electrons exchanged, $E_{t}$ is a scan rate of $5 \mathrm{mV} / \mathrm{s}$. Utmost care has been taken while recordingopen circuit potential (OCP) when no current was flowing through the working electrode/solution interface.

the applied potential and $E_{c}^{\theta}$ is the formal potential. The $n$ has a very small influence on the value of faradaic current but it has a large effect on the transport of electroactive species towards the working electrode.

The capacitive and faradaic current were recorded separately to an approximate level. At low concentration, the capacitive current, $l_{c}$ is maximum and at high concentration faradaic current was maximum [30, 31]. The magnitude of the faradaic current, $l_{f}$ was directly proportional to concentration of electroactive species present at the surface of the working electrode and hence provides quantitative information about pathogens. The value of capacitive current does not change with 

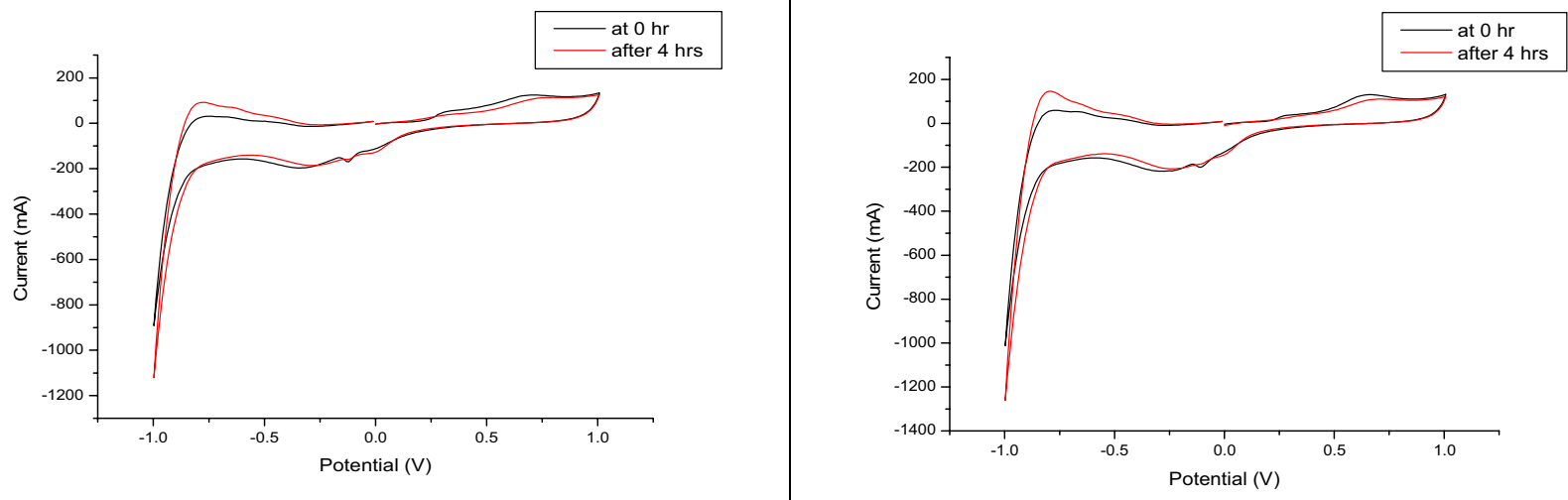

(a). Cyclic voltammetry curve for pure PBS buffer solution at 0 and $4 \mathrm{~h}$ of stirring. (b). Cyclic voltammetry curve for PBS buffer solution in the presence of $\mathrm{CuO}$ NPs at 0 and $4 \mathrm{~h}$ of stirring.
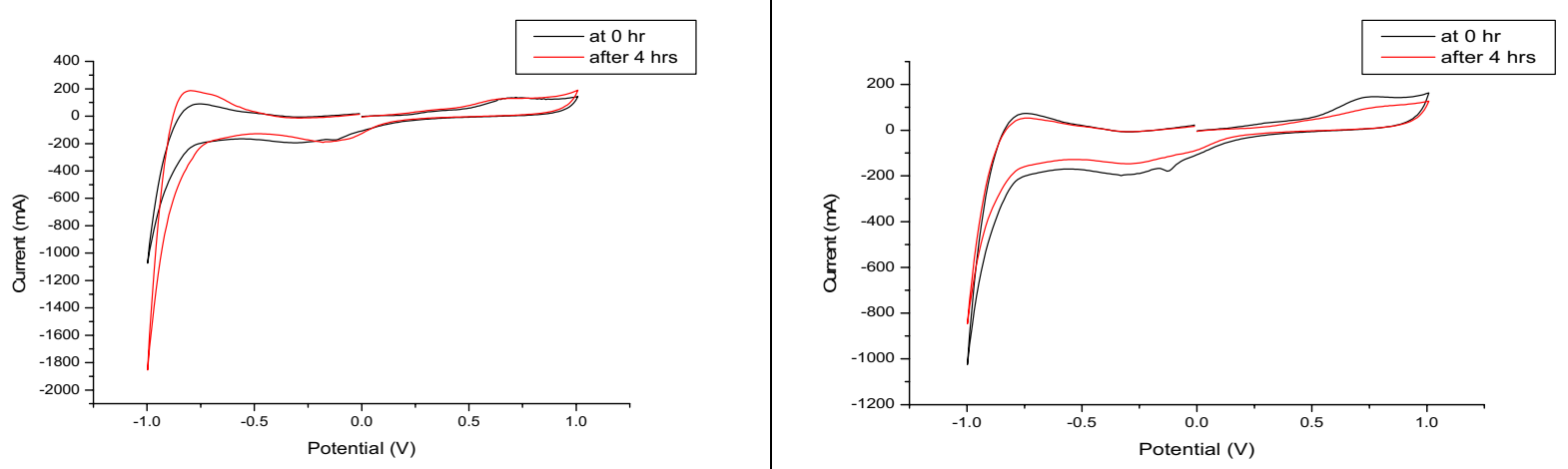

(c). Cyclic voltammetry curve for PBS buffer solution in the presence of $S$. aureus at 0 and $4 \mathrm{~h}$ of heating.

(d).

Cyclic voltammetry curve for PBS buffer solution $+S$. aureus + CuO NPs $(100$ ppm) at 0 and $4 \mathrm{~h}$ of stirring.
Fig. 3 Cyclic voltammetry curves for the electrochemical characterization of $S$. aureus pathogenic bacteria. IUPAC convention was used for representing the Cyclic Voltammogram. Voltammogram were recorded in $1.0 \times 10^{7} \mathrm{CFU} / \mathrm{mL}$ of $S$. aureus in $50 \mathrm{~mL}$ of PBS buffer solution, $1 \mathrm{M} \mathrm{KCl}$ solution was used as supporting electrolyte. All the potentials were measured w.r.t. $\mathrm{Ag} / \mathrm{AgCl}$ reference electrode at a scan rate of $5 \mathrm{mV} / \mathrm{s}$
S. aureus concentration. The faradaic current is directly proportional to the rate of diffusion of $S$. aureus at the surface of the working electrode (Fick's law of diffusion). The capacitive current results due to the formation of electrified interface and is given in Eq. (3) [32]:
$I_{c}=-q \frac{\partial A}{\partial t}-A \frac{\partial q}{\partial t}$

Here, $A$ is the surface area, $q$ is the charge present at the interface and $t$ is the time. Capacitive current can also be expressed in terms of the electrical potential gradient, Eq. (4): 


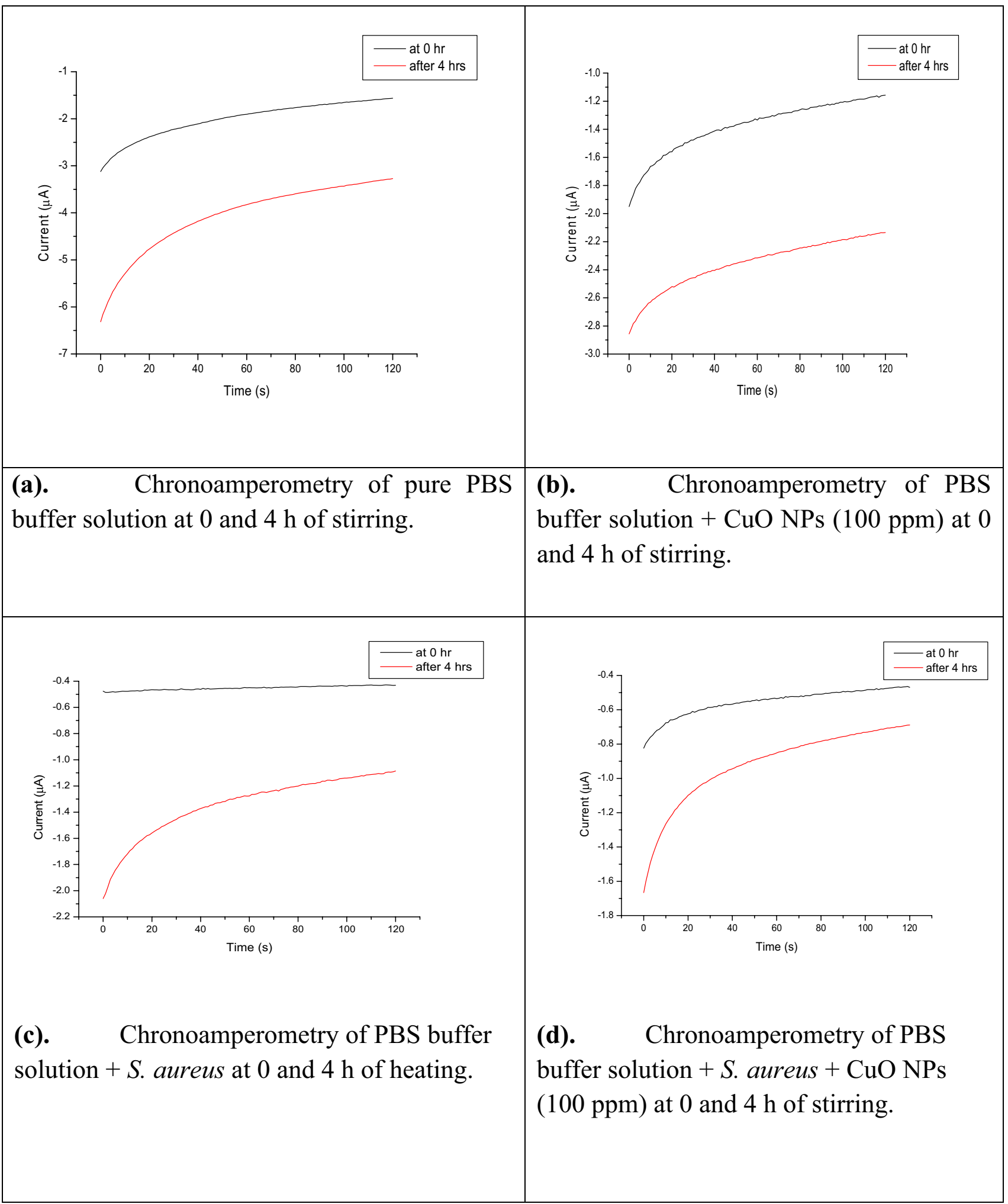

Fig. 4 Chronoamperometry curves for the electrochemical characterization of $S$. aureus pathogenic bacteria. Chroamperometric curves were recorded at anodic step potential of $100 \mathrm{mV}$ from its equilibrium value. Potential were recorded with a $3 \mathrm{~mm}$ graphite working electrode w.r.t. $\mathrm{Ag} / \mathrm{AgCl}$ reference electrode in $1.0 \times 10^{7} \mathrm{CFU} / \mathrm{mL}$ of S. aureus in $50 \mathrm{~mL}$ of PBS buffer solution in presence and absence of $100 \mathrm{ppm}$ of $\mathrm{CuO}$ NPs at $25^{\circ} \mathrm{C}$ and at constant $\mathrm{pH}$ of 7 


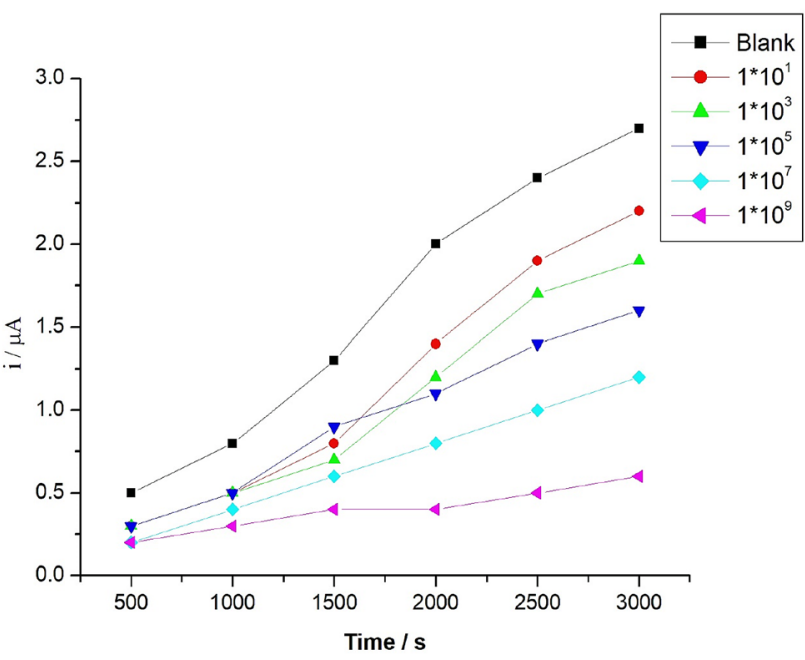

Fig. 5 Chronoamperometric technique showing variation of current density $\left(\mu \mathrm{A} / \mathrm{cm}^{2}\right)$ with time $(\mathrm{s})$ at different concentration of S. aureus pathogenic bacteria in presence of sodium phosphate buffer solution

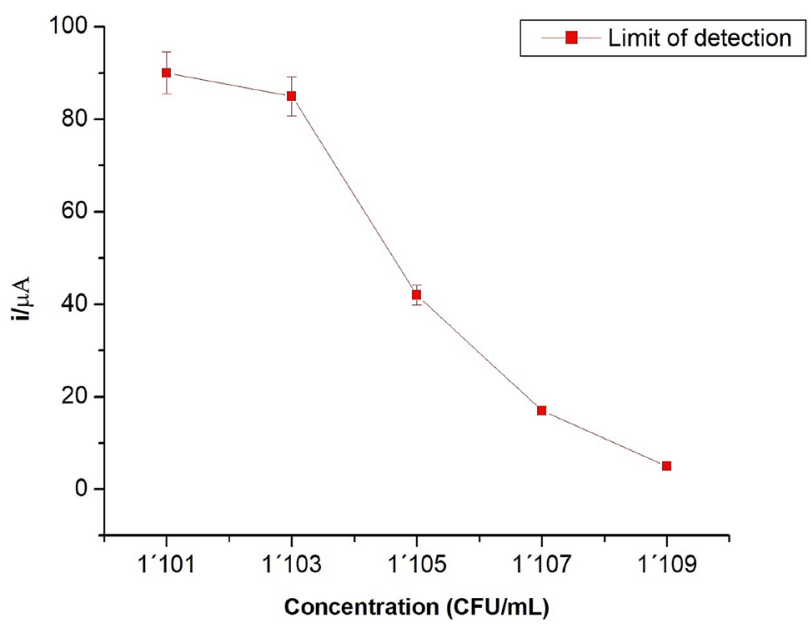

Fig. 6 Current $\left(\mu \mathrm{A} / \mathrm{cm}^{2}\right)$ versus concentration $(\mathrm{CFU} / \mathrm{mL})$ response of electrochemical sensor exposed to different concentration of bacterial i.e., $S$. aureus in presence of $0.1 \mathrm{M}$ sodium phosphate buffer solution at a constant $\mathrm{pH}$ of 7 and $4{ }^{\circ} \mathrm{C}$. Standard assay conditions were used for each assay. Limit of detection observed by Ghali et al. was $5 \times 10^{6} \mathrm{CFU} / \mathrm{mL}$ [9], $5 \times 10^{3} \mathrm{CFU} / \mathrm{mL}$ by Chibli et al. [10] and $2 \times 10^{7}$ cells $/ \mathrm{mL}$ by Haung et al. [7]

$I_{c}=-q \frac{\partial A}{\partial t}-A C_{d l} \frac{\partial E}{\partial t}$

Here, $\mathrm{E}$ is the potential created along with the interface due to the separation of charge. Hence, the capacitive current is dependent on the surface area gradient and potential gradient [33].

It was observed that the addition of CuO NPs sharpens the oxidative and reductive peak in CV experiments.

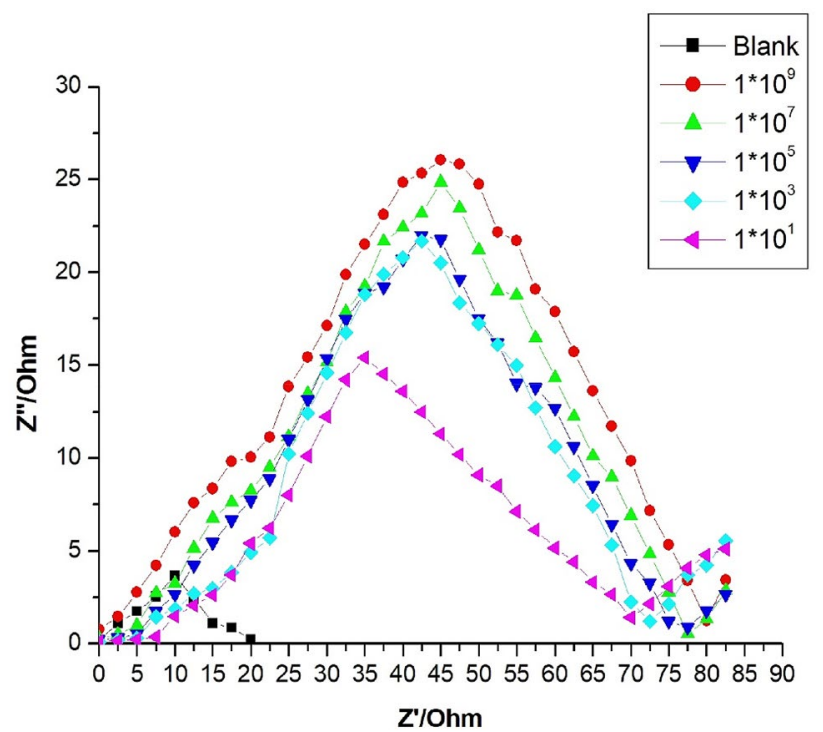

Fig. 7 Nyquist plots of S. aureus pathogenic bacteria at different concentrations. EIS experiments were performed at OCP in the frequency range of 0.1 to $10,000 \mathrm{~Hz}$ with an $\mathrm{AC}$ amplitude voltage of $0.05 \mathrm{~V}$ after a time interval of every $2 \mathrm{~s}$. The blank solution contains SPBS and $0.1 \mathrm{M} \mathrm{KCl}$ solution

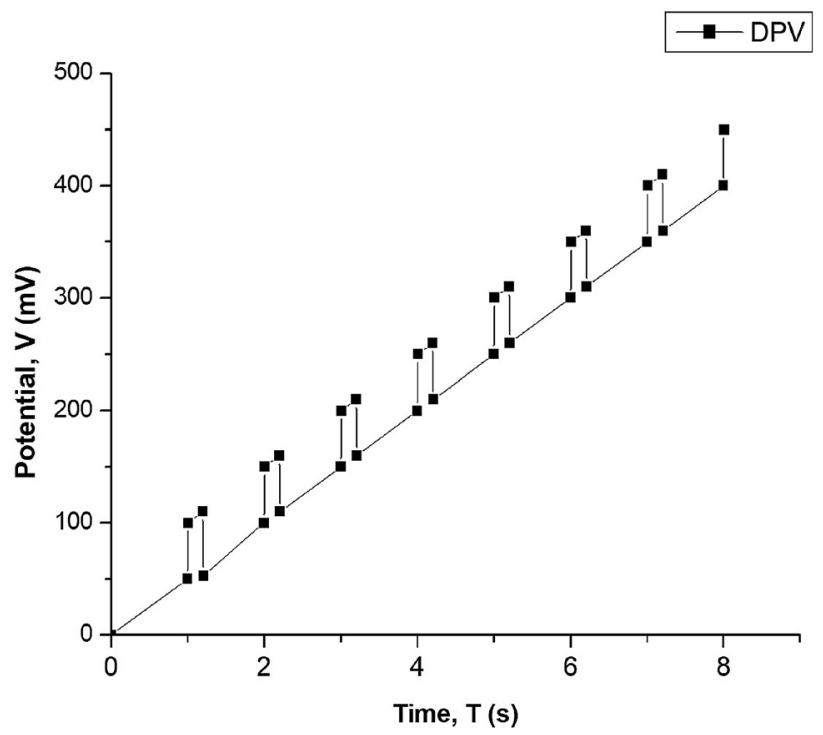

Fig. 8 Differential pulse voltammetry technique showing potential time function of $S$. aureus with a linear incremental scan rate i.e., $5 \mathrm{mV} / \mathrm{s}$ with a pulse of $50 \mathrm{mV}$ at every second for a duration of $100 \mathrm{mS} .0 .1 \mathrm{~mol} / \mathrm{L} \mathrm{KCl}$ solution was used as a supporting electrolyte

Heating of the analyte at $70^{\circ} \mathrm{C}$ and the addition of CuO NPs (100 ppm) has the same effect on CV. An oxidative anodic peak, $E_{p a}$ at $-0.85 \mathrm{~V}$, mid-point potential, $E_{M I D}=-0.075 \mathrm{~V}$, $\Delta E_{p}=-0.15 \mathrm{~V}$, maximum current intensity in anodic direction, $I_{p}=189.1 \mathrm{~mA}$, reductive anodic peak, $E_{p c}=0.75 \mathrm{~V}$, 


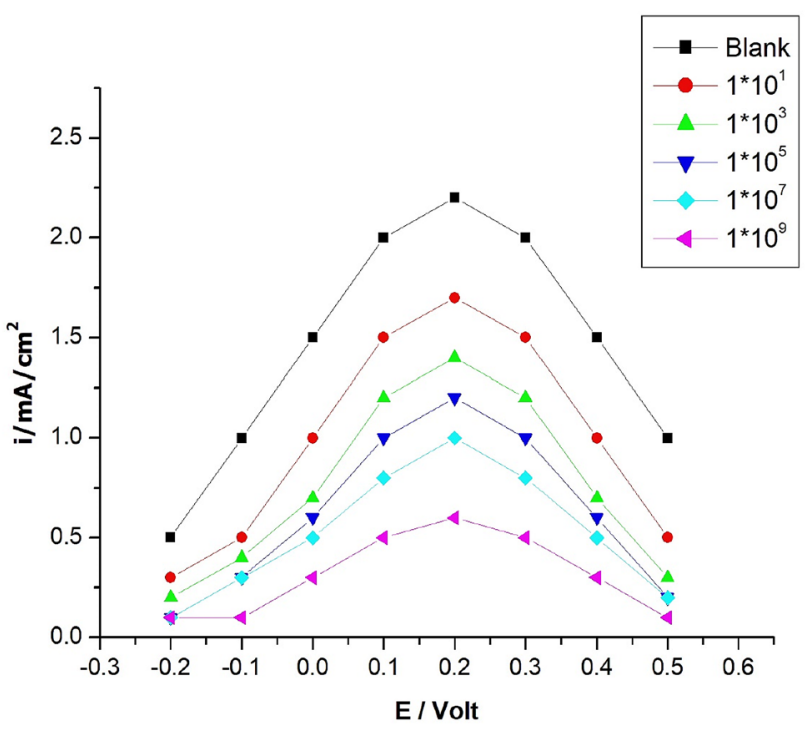

Fig. 9 Differential pulse voltammetry technique showing variation of current density with increase in potential at different concentration of $S$. aureus pathogenic bacteria. A linear incremental scan rate i.e., $5 \mathrm{mV} / \mathrm{s}$ was kept and a pulse of $50 \mathrm{mV}$ was given at every second for a duration of $100 \mathrm{mS} .0 .1 \mathrm{~mol} / \mathrm{L} \mathrm{KCl}$ solution was used as a supporting electrolyte. The blank solution contains SPBS and $0.1 \mathrm{M}$ $\mathrm{KCl}$ solution

Table 4 Electrochemical impedance parameters in absence and presence of different concentrations of $S$. aureus pathogenic bacteria

\begin{tabular}{lllll}
\hline $\begin{array}{l}\text { Concentration of } \\
\begin{array}{l}\text { S. aureus (CFU/ } \\
\mathrm{mL})\end{array}\end{array}$ & $\begin{array}{l}C_{d l} \\
\left(\times 10^{-3} \mathrm{~F} \mathrm{~cm}^{2}\right)\end{array}$ & $\begin{array}{l}R_{c t} \\
\left(\Omega \mathrm{cm} \mathrm{cm}^{2}\right)\end{array}$ & $\begin{array}{l}Z_{w} \\
\left.(\mathrm{ohm} \mathrm{s})^{-1 / 2} \mathrm{~Hz}^{-1}\right)\end{array}$ & $\lambda$ \\
\hline Blank & 1.7 & 20.8 & 42.62 & 7.0 \\
$1 \times 10^{1}$ & 1.4 & 70.21 & 87.74 & 6.1 \\
$1 \times 10^{3}$ & 0.42 & 76.61 & 93.27 & 7.4 \\
$1 \times 10^{5}$ & 0.61 & 77.11 & 104.85 & 7.7 \\
$1 \times 10^{7}$ & 0.54 & 79.63 & 157.62 & 8.4 \\
$1 \times 10^{9}$ & 0.43 & 84.45 & 207.34 & 8.7 \\
\hline
\end{tabular}

formal potential, $E_{c}{ }^{\theta}=0.075 \mathrm{~V}$ and OCP value of $0.347 \mathrm{mV}$ (Table 3) are characteristics of $S$. aureus.

\subsection{Chronoamperometric method}

Figure 4(a) shows the chronoamperometry of SPBS at zero and after $4 \mathrm{~h}$ of continuous stirring. An increase in current density was observed after $4 \mathrm{~h}$ of stirring. Figure $4(\mathrm{~b})$ shows the chronoamperometry curves of SPBS + CuO NPs. An increase in current density was observed after $4 \mathrm{~h}$ of continuous stirring. Figure 4(c) shows the chronoamperometry curve of SPBS + S. aureus after heating at $70^{\circ} \mathrm{C}$. Figure 4 (d) shows the chronoamperometry curve of SPBS, $S$. aureus and $\mathrm{CuO}$ NPs. An increase in the current density was observed after $4 \mathrm{~h}$ of stirring in case of SPBS [19]. The current density decreases after $4 \mathrm{~h}$ of stirring in presence of CuO NPs (Fig. 4(a, b)). The 100 ppm CuO NPs in the system also results in the decrease in current density but the decrease is not as significant as compared to heating at $70^{\circ} \mathrm{C}$. Figure 5 shows the amperometric curves of $S$. aureus pathogenic bacteria at different concentrations. The values of current density decrease with an increase in bacterial concentration from $1 \times 10^{9}$ to $1 \times 10^{1} \mathrm{CFU} / \mathrm{mL}$ (Fig. 5). As more and more bacterial colonies were added in the system, interface resistance increases which results in a decrease in the current density. The value of the current density decreases appreciably after $1 \times 10^{7} \mathrm{CFU} / \mathrm{mL}$. Figure 6 shows the variation of current density with S. aureus concentration. A decrease in current density was observed with $S$. aureus concentration. The value of current density decreases to $4 \mu \mathrm{A} / \mathrm{cm}^{2}$ (almost negligible) at $1 \times 10^{9} \mathrm{CFU} /$ $\mathrm{mL}$ of S. aureus. A lower detection limit of $1 \times 10^{9} \mathrm{CFU} / \mathrm{mL}$ was shown by our sensor in comparison to $5 \times 10^{6} \mathrm{CFU} / \mathrm{mL}$ observed by Ghali et al. [9], $5 \times 10^{3} \mathrm{CFU} / \mathrm{mL}$ observed by Chibli et al. [10], and $2 \times 10^{7}$ cells $/ \mathrm{mL}$ observed by Haung et al. [7]. In comparison with literature data, it was found that the lower and upper detection limit and concentration range for the detection of $S$. aureus by our electrochemical sensor was much better than reported in the literature.

\subsection{Impedance spectroscopy technique}

Impedance spectroscopic study was carried out at OCP in the frequency range $0.1-10,000 \mathrm{~Hz}$ with an $\mathrm{AC}$ amplitude voltage of $0.05 \mathrm{~V}$ after a time interval of $2 \mathrm{~s}$. Figure 7 shows Nyquist plots in the presence and absence of different concentrations of $S$. aureus. The charge transfer resistance, $R_{c t}$ was found to increase with increase in $S$. aureus concentration. An increase in $R_{c t}$ indicates an increase in interface resistance. The thickness of the electrified interface increases as more and more pathogenic bacteria reaches the interface leading to an increase in charge transfer resistance [34, 35]. Table 4 shows the values of doublelayer capacitance $\left(C_{d l}\right)$, charge transfer resistance $\left(R_{c t}\right)$, and interaction parameter $(\lambda)$ at different concentrations of $S$. aureus.

\subsection{Differential pulse voltammetry (DPV) method}

Since the concentration of BWAs used by the terrorist is very less. Hence, DPV technique was used for the quantitative estimation of $S$. aureus bacteria. A linear incremental scan rate i.e., $5 \mathrm{mV} / \mathrm{s}$ was kept and a pulse of $50 \mathrm{mV}$ was given at every second for a duration of $100 \mathrm{mS} .0 .1 \mathrm{~mol} / \mathrm{L}$ $\mathrm{KCl}$ solution was used as a supporting electrolyte. The 


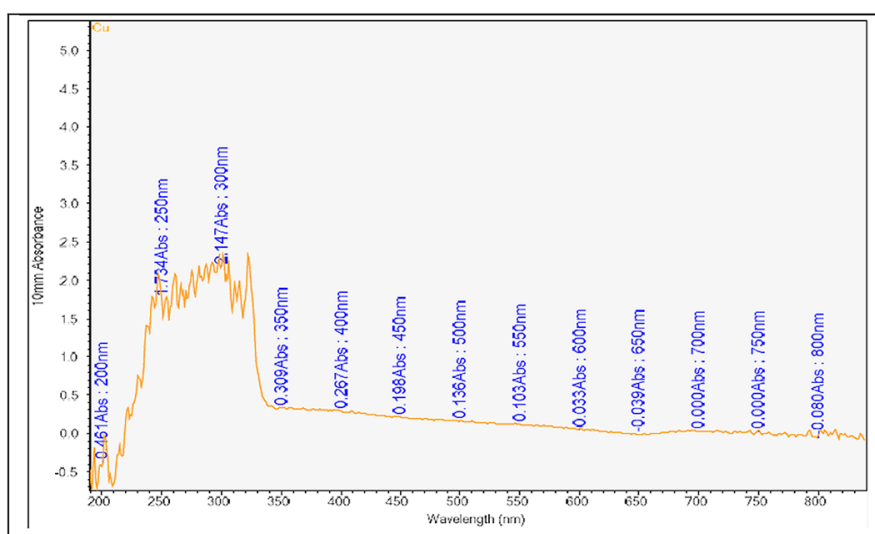

(a). UV- Visible spectra of CuO NPs.

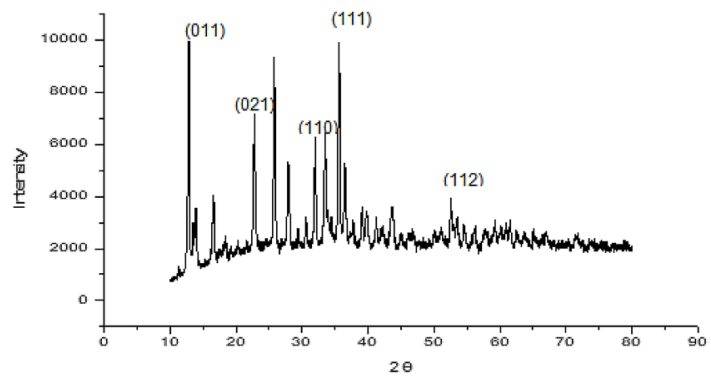

(c). XRD pattern of $\mathrm{CuO}$ NPs.

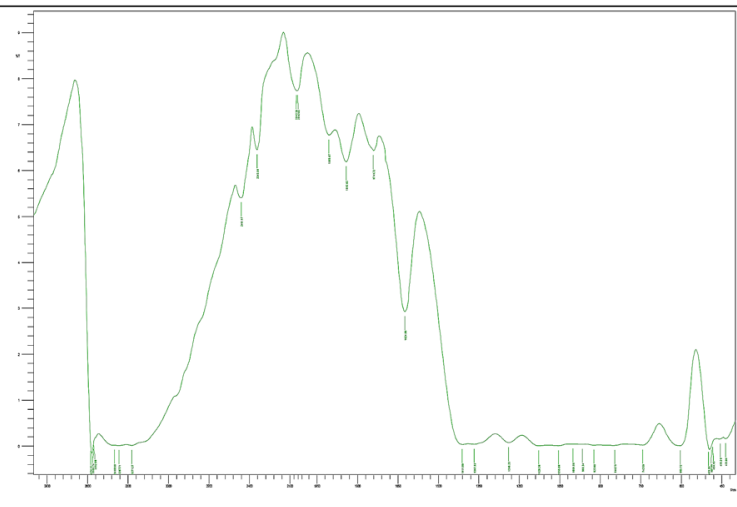

(b). FTIR spectra of $\mathrm{CuO} \mathrm{NPs.}$

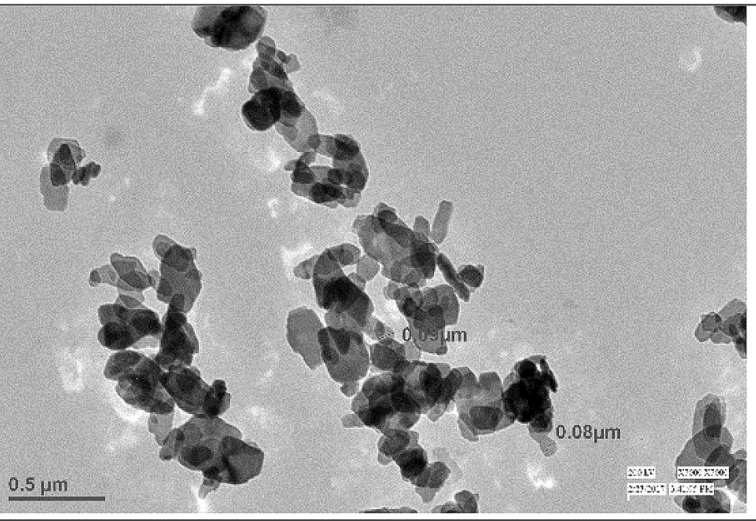

(d). TEM image of CuO NPs.

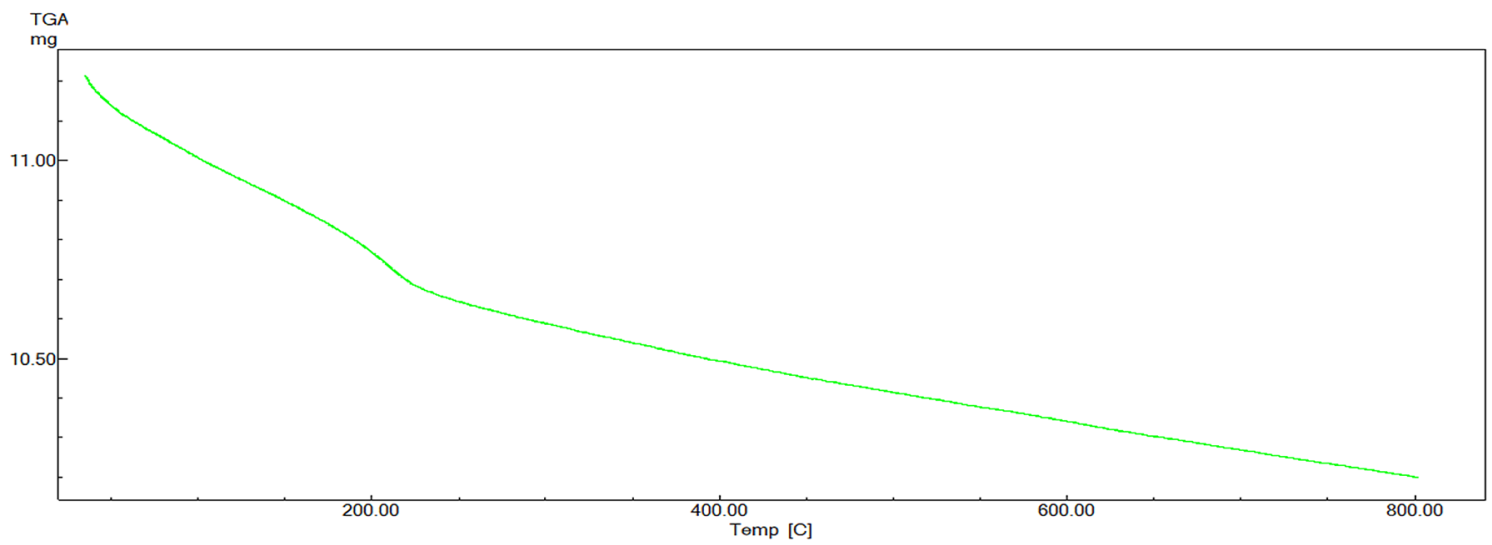

(e). Differential Thermal Analysis (DTA) of CuO NPs. DTA analysis was performed at a scan rate of $5^{\circ} \mathrm{C} / \mathrm{min}$ in inert nitrogen gas atmosphere.

Fig. 10 Characterization of CuO NPs by UV-visible, FTIR, XRD, TEM and DTA techniques 
potential time function obtained from DPV is shown in Fig. 8. The potential was found to increase linearly with time and shows a linear potential pulse signal at every second. Figure 9 shows DPV curves between current density and potential at different concentrations of $S$. aureus. It is clear from Fig. 9 that the value of current density first increases and then decreases with an increase in potential from -0.2 to $0.5 \mathrm{~V}$. It was observed that the value of limiting current density decreases from 2.25 to $0.5 \mathrm{~mA} /$ $\mathrm{cm}^{2}$ with an increase in the concentration of $S$. aureus at a constant potential. The lower detection limit of a novel electrochemical sensor was found to be $1 \times 10^{9} \mathrm{CFU} / \mathrm{mL}$ as observed from DPV (Figs. 6 and 9).

The CV (Fig. 3) and DPV potential time function plot (Fig. 8) tells us that peak potential, $E_{\text {peak }}$ is almost equal to half-wave potential, $E_{1 / 2}$. Although the value of the diffusion coefficient of the oxidized and reduced form of electroactive species is equal but oxidative and reductive current intensity peak is different $[36,37]$. The formal potential, $E_{C}^{\theta}$, was also calculated which is equal to half of the sum of $E_{p a}$ and $E_{p c}$ and is termed as mid-peak potential in CV. Mid peak potential often coincides with half-wave potential. Mid peak potential is related to formal potential by the Eq. (5).

$E_{\text {mid }}=E_{C}^{\theta}+\frac{R T}{2 n F} \ln \left(\frac{D_{\text {Red }}}{D_{\text {Oxid }}}\right)$

Here, $D_{\text {red }}$ and $D_{\text {Oxid }}$ represent the diffusion coefficient for reduced and oxidized form present at the surface of the working electrode [38, 39].

The formal potential is characteristics for a particular electroactive species and helps in the qualitative estimation of species present at the surface of the working electrode. $E p$ is the peak maximum potential in the either anodic or cathodic direction from baseline in CV. Ep is the same as formal potential in alternating current voltammetry and square wave voltammetry but in DPV it is different and is given by the Eq. (6).

$E_{P}=E_{C}^{\theta}-\frac{\Delta E_{\text {pulse }}}{2}$

Formal potential allows us the determination of Gibbs free energy of oxidation/reduction process, acidity constants $\left(p K_{a}\right)$, stability constants of complex formed, solubility constant [40-43]. It was also observed that the working electrode used in CV and DPV acts as electrocatalysis as it increases electrode reactions without being consumed during the electrochemical reaction as proved by the stability test of the working electrode for 45 days.

\section{Storage, stability, current response, and reusability of the electrochemical sensor}

Figure 11 shows the storage, stability, and reusability of the electrochemical sensor tested for continuous 45 days. Figure 11 (a) shows the storage behavior of specially designed and fabricated working electrode-based sensor in $0.1 \mathrm{M}$ SPBS, $\mathrm{pH} 7$, and at $4{ }^{\circ} \mathrm{C}$. The same standard assay conditions were used for each experiment $[44,45]$. Figure 11 (b) shows the effect of $\mathrm{pH}$ on the response of the electrochemical sensor. The two buffers solutions used for maintain constant $\mathrm{pH}$ are sodium succinate ( $\mathrm{pH}$ range $4.5-5.5$ ) and sodium phosphate ( $\mathrm{pH}$ range 6.0-8.0). Figure 11(c) illustrates the influence of temperature on the current response of a novel electrochemical sensor. The same standard test conditions were used except for the incubation temperature which was varied from 20 to $70^{\circ} \mathrm{C}$. The number of observations made was three. The electrochemical sensor lost $50 \%$ of its activity after its regular testing i.e. 100 times in 45 days when kept in $0.1 \mathrm{M} \mathrm{SPBS}, \mathrm{pH} 7$, and at $4{ }^{\circ} \mathrm{C}$. The current response of the electrochemical sensor was checked at different $\mathrm{CFU} / \mathrm{mL}$ in presence of $0.1 \mathrm{M} \mathrm{SPBS}$ at $\mathrm{pH} 7$ and $4{ }^{\circ} \mathrm{C}$ (Fig. 6). The current response of the amperometric sensor decreases with increase in bacterial concentration at a constant potential (Fig. 6). The current response of the investigated electrochemical sensor was found linear with a correlation coefficient, $R^{2}=0.991$.

\section{Conclusions}

A novel electrochemical sensor free from enzyme, protein, and nucleic acid was developed for the quick, accurate, and reliable detection of disease-causing pathogenic bacteria. Different electrochemical characterization techniques were used for the qualitative and quantitative estimation of $S$. aureus pathogenic bacteria i.e., LRP, CV, chronoamperometry, EIS, and DPV. The definite values of OCP, oxidative and reductive peak, $E_{p a^{\prime}}$ mid-point potential $\left(E_{M I D}\right), \Delta E_{p}$, limiting current intensity $\left(I_{p}\right)$, reductive anodic peak $\left(E_{p c}\right)$, and formal potential $\left(E_{c}{ }^{\prime}\right)$ were recorded at different potential, concentration and time. Heating of samples at $70^{\circ} \mathrm{C}$ for $4 \mathrm{~h}$ and addition of $\mathrm{CuO}$ NPs (100 ppm) has the same effect, i.e., both results in the decrease in current density, opencircuit potential, and killing of pathogenic bacteria. $S$. aureus shows a characteristic oxidative anodic peak at $189.1 \mathrm{~mA}, E_{M I D}=-0.075 \mathrm{~V}, \Delta E_{p}=-0.15 \mathrm{~V}$, reductive anodic peak, $E_{p c}=0.75 \mathrm{~V}$, formal potential, $E_{c}{ }^{\theta}=0.075 \mathrm{~V}$ and an OCP of $0.347 \mathrm{mV}$. A decrease in the current density was observed with time and concentration of $S$. aureus. The 


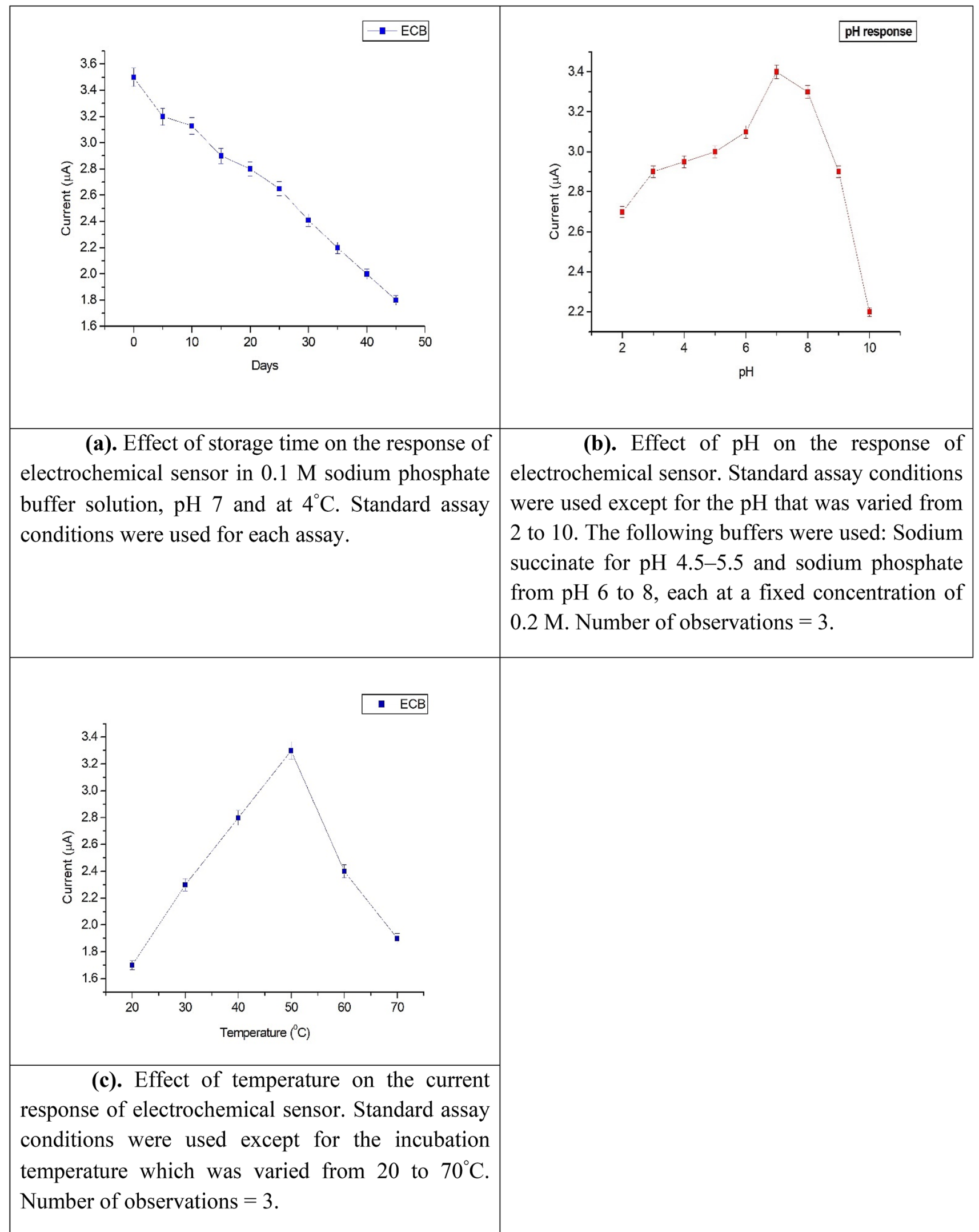

Fig. 11 Storage, stability and reusability of electrochemical sensor tested for continuous 45 days 
electrochemical sensor was tested for 45 days for its storage, stability, and reusability. The current response was found linear with a correlation coefficient of $R^{2}=0.991$. The developed electrochemical sensor was proved very quick, accurate, and reliable in the estimation of pathogenic bacteria to be used as potential biological warfare agents.

Acknowledgments Contributors of this paper are very thankful to Chaudhary Devi Lal University, Sirsa for providing the necessary lab facility for carrying out this research work. We are also very thankful to DRDO, New Delhi for providing financial assistance for this research work.

Author contributions HK planned the experiments, analyzed, interpreted the results, was a major contributor, and is the first and main author for correspondence of the manuscript.B.G. collected samples for the experiments, performed electrochemical resistance polarization, impedance spectroscopy, chronoamperometry, and DPV experiments.

Availability of the data The raw data related to this research article will be made available on the written request to the authors.

\section{Compliance with ethical standards}

Conflict of interest Both authors declare that they have no conflict of interest.

\section{Consent for publication Yes.}

Human and animal rights The reported research work in this paper has not involved any human and animals. No harm was made to any person or animal in carrying out this research work.

\section{References}

1. Kim ES, Christopher B, James BD, Igor LM (2008) Sensors for detecting biological agents. Mat Today 11:38-49. https://doi. org/10.1016/S1369-7021(08)70018-X

2. Pohanka M (2019) Current trends in the biosensors for biological warfare agents assay. Materials (Basel) 12(14):2303. https://doi. org/10.3390/ma12142303

3. Mansuriya BD, Altintas Z (2020) Applications of graphene quantum dots in biomedical sensors. Sensors (Basel) 20(4):1072. https://doi.org/10.3390/s20041072

4. Diauudin FN, Rashid JIA, Knight VF, Yunus W, Md ZW, Ong KK, Kasim NAM, Halim NA, Noor SAM (2019) A review of current advances in the detection of organophosphorus chemical warfare agent-based biosensor approaches. Sensing Bio-Sensing Res 26:100305. https://doi.org/10.1016/j.sbsr.2019.100305

5. Bhargav D, Mansuriya AZ (2020) Graphene quantum dot-based electrochemical immunosensors for biomedical applications. Materials (Basel) 13(1):96. https://doi.org/10.3390/ma13010096

6. Singh S, Solanki PR, Malhotra BD (2006) Covalent immobilization of cholesterol esterase and cholesterol oxidase on polyaniline films for application to cholesterol biosensor. Anal Chim Acta 568:126-132. https://doi.org/10.1016/j.aca.2005.10.008
7. Huang SJ, Wang YJ, Cai QY, Fang JD (2010) Detection of Staphylococcus aureus in different liquid mediums using wireless magnetoelastic sensor. Chinese J Anal Chem 38(1):105-108. https:// doi.org/10.1016/S1872-2040(09)60018-9

8. XuY, Wang LP, Zhong YQ, Zheng YH (2013) Experimental research of fluid flow and effective thermal parameters in micro-particle packed bed as a thermal biosensor reactor under constant wall temperature conditions. Exp Thermal Fluid Sci 45:34-42. https ://doi.org/10.1016/j.expthermflusci.2012.10.005

9. Ghali $\mathrm{H}$, Chibli $\mathrm{H}$, Nadeau JL, Bianucci P, Peter YA (2016) Real-time detection of Staphylococcus aureus using whispering gallery mode optical microdisks. Biosensors (Basel) 6(2):20. https://doi. org/10.3390/bios6020020

10. Chibli H, Ghali H, Park S, Peter YA, Nadeau JL (2014) Immobilized phage proteins for specific detection of staphylococci. Analyst 139(1):179-186. https://doi.org/10.1039/c3an01608k

11. Chang-Jun J, Kim JH, Won YB, Lee YE, Choi TW, Ju SY, Youn H, Helmann JD, Lee JW (2015) Staphylococcus aureus PerR is a hypersensitive hydrogen peroxide sensor using Fe-mediated histidine oxidation. J Biol Chem 290(33):20374-20386. https:// doi.org/10.1074/jbc.M115.664961

12. Crowley EL, O'Sullivan CK, Guilbault GG (1999) Increasing the sensitivity of Listeria monocytogenes assays: evaluation using ELISA and amperometric detection. Analyst 124(3):295-299. https://doi.org/10.1039/a806875e

13. Zhu Z, Fengliei G, Jianping L, Haifeng D (2012) A competitive strategy coupled with endonuclease-assisted target recycling for DNA detection using silver-nanoparticle-tagged carbon nanospheres as labels. Chem Eur J 18(43):13871-13876. https ://doi.org/10.1002/chem.201201307

14. Fenglei G, Fuyi Z, Songjie C, Yao Y, Jing W, Dengyang Y, Dequin G, Po W (2017) Proximity hybridization triggered rolling-circle amplification for sensitive electrochemical homogeneous immunoassay. Analyst 142:4308-4316. https://doi.org/10.1039/ C7AN01434A

15. Joan CK, Rajasekhar CR, Nicholas R, Gan GR (2020) A novel electrochemical sensor for selective determination of theophylline in pharmaceutical formulations. J Taiwan Inst Chem Eng 111:228-238. https://doi.org/10.1016/j.jtice.2020.05.007

16. Chokkareddy R, Thondavada N, Bhajanthri NK, Redhi GG (2019) An amino functionalized magnetite nanoparticle and ionic liquid based electrochemical sensor for the detection of acetaminophen. Anal Methods 11(48):6204-6212. https://doi. org/10.1039/C9AY01743G

17. Rajasekhar C, Natesh KB, Gan GR (2017) A novel electrode architecture for monitoring Rifampicin in various pharmaceuticals. Int J Electrochem Sci 12:9190-9203. https://doi.org/10.20964 /2017.10.13

18. Chokkareddy R, Bhajanthri NK, Gan GR, Dhirendra GR (2018) Ultra-sensitive electrochemical sensor for the determination of pyrazinamide. Curr Anal Chem 14(4):391-398. https://doi. org/10.2174/1573411013666170530105000

19. Kumar H, Rani R (2013) Development of biosensor for the detection of biological warfare agents: its issues \& challenges. Sci Prog 96(3):294-308. https://doi.org/10.3184/003685013X13777 066241280

20. Kumar H, Bhawana (2016) Development of amperometric biosensor for the detection of Vibrio vulnificus as biological weapon. Int J Adv Res Sci Eng 5(08):751-761

21. Kumar H, Bhawana (2016) Amperometric biosensor for the detection of Enterobacteraerogenes as biological weapon. Elixir Int J 90:37565-37570

22. Kumar H, Bhawana (2016) Development of amperometric biosensor for the detection of Vibrio vulnificus as biological weapon. Ind J Adv Chem Sci 4(2):130-137 
23. Kumar H, Bhawana (2015) Development of electrochemical biosensor for the detection of Klebsiella pneumoniae as biological weapon. Res J Chem Sci 5(12):88-97

24. Bard XJ, Faulkner LR (2000) Electrochemical methods: fundamentals and applications, 2nd edn. Wiley, New York

25. Boistelle R, Astier JP (1998) Crystallization mechanisms in solution. J Crystal Growth 90:14-30

26. Armstrong FA, Heering HA, Hirst J (1997) Reaction of complex metalloproteins studied by protein-film voltammetry. Chem Soc Rev 26:169. https://doi.org/10.1039/CS9972600169

27. Kim BH, Kim HJ, Hyun MS, Park DH (1999) Direct electrode reaction of Fe(III) reducing bacterium, Shewanella putrefaciens. J Microbiol Biotechnol 9:127-131

28. Compton RG, Perkin SJ, Gamblin DP, Davis J, Marken F, Padden AN, John P (2000) Clostridium isatidis colonised carbon electrodes: voltammetric evidence for direct solid state redox processes. New J Chem 24:179-181. https://doi.org/10.1039/A9091 $72 \mathrm{~F}$

29. Setterington EB, Alocilja EC (2012) Electrochemical biosensor for rapid and sensitive detection of magnetically extracted bacterial pathogens. Biosensors 2(1):15-31. https://doi.org/10.3390/ bios2010015

30. Chowdhury AD, De A, Chaudhuri CR, Bandyopadhyay K, Sen $P$ (2012) Label-free polyaniline based impedimetric biosensor for detection of E. coli 0157:H7 Bacteria. Sens Actuators B 171:916-923. https://doi.org/10.1016/j.snb.2012.06.004

31. Wan Y, Zhang D, Wang Y, Hou B (2010) A 3D-impedimetric immunosensor based on foam $\mathrm{Ni}$ for detection of sulfate-reducing bacteria. Electrochem Commun 12(2):288-291. https://doi. org/10.1016/j.elecom.2009.12.017

32. Bhardwaj J, Devarakonda S, Kumar S, Jang J (2017) Development of a paper-based electrochemical immunosensor using an antibody-single walled carbon nanotubes bio-conjugate modified electrode for label-free detection of foodborne pathogens. Sens Actuators B 253:115-123. https://doi.org/10.1016/j. snb.2017.06.108

33. Fei J, Dou W, Zhao G (2016) Amperometric immunoassay for the detection of Salmonella pullorum using a screen-printed carbon electrode modified with gold nanoparticle-coated reduced graphene oxide and immunomagnetic beads. Microchim Acta 183(2):757-764. https://doi.org/10.1007/s00604-015-1721-3

34. Maalouf R, Fournier-Wirth C, Coste J, Chebib H, Saïkali Y, Vittori O, Errachid A, Cloarec JP, Martelet C, Jaffrezic-Renault N (2007) Label-free detection of bacteria by electrochemical impedance spectroscopy: comparison to surface plasmon resonance. Anal Chem 79(13):4879-4886. https://doi.org/10.1021/ac070085n

35. Lu L, Chee G, Yamada K, Jun S (2013) Electrochemical impedance spectroscopic technique with a functionalized microwire sensor for rapid detection of foodborne pathogens. Biosens Bioelectron 42:492-495. https://doi.org/10.1016/j.bios.2012.10.060
36. Stojek Z (2010) Pulse voltammetry. In: Scholz F (ed) Electroanalytical methods. Guide to experiments and applications. Springer, Berlin, p 107

37. Molina A, Gonzalez J (2015) Pulse voltammetry in physical electrochemistry and electroanalysis. In: Scholz F (ed) Monographs in electrochemistry. Springer, Berlin

38. Li L, Chen Z, Wang S, Jin X, Yang L, Liu G, Zhao J (2017) Highly selective detection of Escherichia coli O157: H7 based on micro-gapped interdigitated electrode arrays. Biotechnol Biotechnol Equip 31:1070-1078. https://doi.org/10.1080/13102 818.2017.1335178

39. Wang Y, Alocilja EC (2015) Gold nanoparticle-labeled biosensor for rapid and sensitive detection of bacterial pathogens. J Biol Eng 9(1):16. https://doi.org/10.1186/s13036-015-0014-z

40. Barreiros DS, Azevedo M, Agusil S, Prieto-Simon J, Sporer B, Torrents C, Juarez E, Teixeira A, Samitier V (2015) Label-free ITObased immunosensor for the detection of very low concentrations of pathogenic bacteria. Bioelectrochemistry 101:146-152. https://doi.org/10.1016/j.bioelechem.2014.09.002

41. Jayamohan $H$, Gale B K, Minson B, Lambert CJ, Gordon N, Sant H $J$ (2015) Highly sensitive bacteria quantification using immunomagnetic separation and electrochemical detection of guaninelabeled secondary beads. Sensors 15(5):12034-12052. https:// doi.org/10.3390/s150512034

42. Setterington EB, Alocilja EC (2011) Rapid electrochemical detection of polyaniline-labeled Escherichia coli O157: H7. Biosens Bioelectron 26(5):2208-2214. https://doi.org/10.1016/j. bios.2010.09.036

43. Huang H, Liu M, Wang X, Zhang W, Yang DP, Cui L, Wang X (2016) Label-free 3D Ag nanoflower-based electrochemical immunosensor for the detection of Escherichia coli 0157:H7 pathogens. Nanoscale Res Lett 11(1):507. https://doi.org/10.1186/ s11671-016-1711-3

44. Li Y, Fang L, Cheng P, Deng J, Jiang L, Huang H, Zheng J (2013) An electrochemical immunosensor for sensitive detection of Escherichia coli 0157: $\mathrm{H} 7$ using $\mathrm{C} 60$ based biocompatible platform and enzyme functionalized Pt nanochains tracing tag. Biosens Bioelectron 49:485-491. https://doi.org/10.1016/j.foodc hem.2017.02.083

45. Tan F, Leung PH, Liu ZB, Zhang Y, Xiao L, Ye W, Zhang X, Yi L, Yang M (2011) A PDMS microfluidic impedance immunosensor for E. coli O157: $\mathrm{H} 7$ and Staphylococcus aureus detection via an antibody-immobilized nanoporous membrane. Sens Actuators B 159(1):328-335. https://doi.org/10.1016/j.snb.2011.06.074

Publisher's Note Springer Nature remains neutral with regard to jurisdictional claims in published maps and institutional affiliations. 